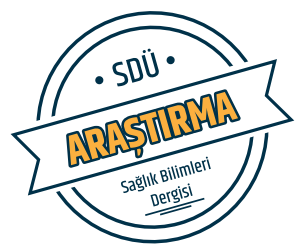

Sdü Sağlık Bilimleri Dergisi / Cilt 11 Sayı 2 / 2020

\title{
Verification Of Percentage Depth-Doses With Monte Carlo Simulation and Calculation Of Mass Attenuation Coefficients For Various Patient Tissues In Radiation Therapy
} Radyoterapide Monte Carlo Simülasyonu ile Yüzde Derin
Dozların Doğrulanması ve Çeşitli Hasta Dokuları İçin
Küitle Zayıflatma Katsayılarının Hesaplanması

Alper Özseven', Ümit Kara²

${ }^{1}$ Süleyman Demirel University, Faculty of Medicine, Department of Radiation Oncology, Isparta, Turkey. ${ }^{2}$ Süleyman Demirel University, Isparta Vocational School of Health Services, Isparta, Turkey.

\begin{abstract}
Objective: First part of this work dedicated to the verification of the percentage depth dose curves that obtained experimentally for $6 \mathrm{MV}$ and $18 \mathrm{MV}$ x-ray photon beams via using Geant4 Monte Carlo simulation. Second part of this study compared the computed mass attenuation coefficients of various human tissues and water between MATLAB and XCOM.
\end{abstract}

Material-Method: The central-axis percentage depth doses of Varian Clinac IX linear accelerator were verified via Monte Carlo simulation (Geant4) with square field sizes (10x10 and $30 \times 30 \mathrm{~cm}^{2}$ ) for $6 \mathrm{MV}$ and $18 \mathrm{MV}$ x-ray photon energies. In addition, mass attenuation coefficients of adipose tissue, blood, muscle, bone, skin and water were computed with MATLAB and were compared with the NIST XCOM data.

Results: Results of the Geant4 modeling were in line with the experimental measurements for percentage depth dose curves. The consistency of Geant 4 with experimental results was more explicit for $6 \mathrm{MV}$ photons with the field size of $10 \times 10 \mathrm{~cm}^{2}$. No statistically significant difference between MATLAB and $\mathrm{XCOM}$ were found for all mentioned human tissues, except for bone ( $p=0.039$ for bone in both genders). The minimum median percentage differences were calculated for water and skin with a result of $1.23 \%$ and $2.19 \%$, respectively.

Conclusions: Geant 4 can be used to predict percentage depth dose curves for medical linacs. Mass attenuation coefficients calculated with MATLAB yielded consistent results with previous studies, which means MATLAB can be used as an alternative simulation tool for estimating mass attenuation coefficients of various human tissues and water.

Keywords: Radiation Therapy, Geant4, MATLAB, Mass Attenuation Coefficient, Percentage Depth Dose.

\section{Özet}

Amaç: Bu çalışmanın ilk kısmında, $6 \mathrm{MV}$ ve $18 \mathrm{MV}$ x-1şını foton demeti için deneysel olarak elde edilen yüzde derin doz eğrilerinin, Geant4 Monte Carlo simülasyonu kullanılarak doğrulanması amaçlanmıștır. Buna ek olarak; çalışmanın ikinci kısmında, MATLAB ve XCOM programları kullanılarak, çeşitli insan dokularının ve suyun kütle zayıflatma katsayıları hesap edilerek karşılaştırıldı.

Materyal-Metot: Varian Clinac IX lineer hizlandırıcı cihazında deneysel olarak ölçülen merkezi eksen yüzde derin dozları; $6 \mathrm{MV}$ ve $18 \mathrm{MV}$ x-1şını foton enerjileri için 10x10 cm² ve $30 \times 30 \mathrm{~cm}^{2}$ alan boyutlarında, Monte Carlo simülasyonu (Geant4) ile hesap edilerek doğrulandı. Ek olarak; kan, kemik, yağ dokusu, kas, deri ve suyun kütle zayıflama katsayıları MATLAB ile hesaplanarak, NIST XCOM verileri ile karşılaştırıldı.

Bulgular: Geant4 modellemesinin sonuçları, yüzde derin doz eğrileri için deneysel ölçümlerle uyumlu bulundu. Geant4' ün; deneysel sonuçlar ile tutarlılığı, 10x10 cm² alan büyüklüğünde $6 \mathrm{MV}$ foton enerjisi için daha belirgindi. MATLAB ve XCOM sonuçları arasında; bahsi geçen tüm insan dokuları için kemik hariç hiçbirinde istatistiksel olarak anlamlı bir fark bulunmadı (her iki cinsiyette kemik için $p=0,039$ ). En düşük medyan yüzde farkı, su ve cilt için sırasıyla \%1,23 ve \%2,19 olarak hesapland1.

Sonuç: Geant4, tıbbi linaklarda, yüzde derin doz eğrilerini hesaplamak için kullanılabilir. MATLAB ile hesaplanan kütle zayıflatma katsayıları önceki çalışmalarda diğer yazılım programları ile elde edilen sonuçlarla tutarlı bulundu. $\mathrm{Bu}$ da, MATLAB'ın çeşitli insan dokularının yanı sıra suyun kütle zayıflama katsayılarını hesap etmek için alternatif bir simülasyon aracı olarak kullanılabileceğini göstermektedir.

Anahtar kelimeler: Radyoterapi, Geant4, MATLAB, Kütle Zayıflatma Katsayısı, Yüzde Derin Doz. 


\section{Introduction}

Radiation has been used in many fields such as medicine, industry and agriculture throughout the years. Of these mentioned fields, medicine can be accepted as the most important and the most extensive field of application for the usage of radiation (1). Radiation is not only used for diagnostic purposes in radiology, but also utilized in the field of radiation therapy for therapeutic purposes (2). Due to growing importance in medicine; radiation is accepted as one of the indispensable tools for both diagnosis and treatment of the diseases.

According to several health organizations and previous studies, cancer is accepted as the deadliest among the whole diseases (3). In order to cure cancer several treatment modalities have been used in recent years. Although surgery and chemotherapy are the primary treatment techniques in several cancer types, radiotherapy still continues to be the only treatment choice for some cancer forms, when the surgery is unfeasible. Moreover, due to that crucial importance of radiotherapy in many types of cancer, treatment delivery accurateness of radiation therapy become vital for the patients dealing with cancer (4). Although various kind of treatment machines that are in use for the delivery of external radiation treatment; in most clinics, linear accelerators (LINAC) and tomotherapy systems are the wellknown ones. In addition to that, verifying the efficiency of treatment machines with simulation software can improve the reliability and practicality of the treatment. In recent years, one of the most preferred simulation software that validate the performance of LINACs is GEANT (GEometry ANd Tracking) that using Monte Carlo codes in its library (5).

Software that based on Monte Carlo method such as Geant4 is a useful research area for medical physicist. The reason behind is that Monte Carlo methods are a platform for introducing data in a specific form in the field of radiology, nuclear medicine and radiotherapy (6).

Geant 4 able to process all types of particles and complex geometries in its libraries. Particularly, Geant4 offers the most formable 3-dimensional geometry representation which has a superiority on all Monte Carlo codes. One of the most tempting property of Geant 4 is its use of modern computer programming methods. Another exceptional characteristic of Geant 4 is that it can simulate geometries in rotation, for instance the moving components of an intensity modulated radiation therapy (IMRT) beam, dynamic multi-leaf collimators (MLCs), arc-based treatment devices, as well as stationary and active parts of imaging systems, etc. $(7,19)$.

In clinical routine, ionizing radiation interacts with all organs and regions in the patient's body. Therefore, it is important to measure the patient dose arising from ionizing radiation and to determine the attenuation properties of various tissue in human body. In order to evaluate the radiation doses received by patients, several materials have been used to model the human tissue and organs (8). Generally, these materials are termed tissue equivalent materials. Moreover, tissue equivalent materials have been regularly used in radiation therapy, as well as in radiology as research materials (9-12).
The linear attenuation or mass attenuation coefficients of any material or tissue can be calculated from the tables prepared previously in literature. In order to be used in such calculations, American National Institute of Standards and Technology (NIST) developed a web computer program called XCOM which was prepared by Berger and Hubbell. This program can determine the mass attenuation coefficients of any material with energy range starting from $1 \mathrm{keV}$ to 100 $\mathrm{GeV}(13)$.

In the energy interval ranging from $100 \mathrm{keV}$ to $25 \mathrm{MeV}$ x-ray photons have been used to explore the interactions of photons with the matter for many years. The total mass attenuation coefficient can be computed by using constituent elements and the photon energy of the matter. In recent years, total mass attenuation coefficient is a useful method for evaluating the procedure in dosimetric applications of these substances $(10,13)$.

In this current study, the central-axis percentage depth doses of Varian Clinac IX linear accelerator were verified via Monte Carlo simulation (Geant4) with square field sizes (10x10 and $30 \times 30 \mathrm{~cm}^{2}$ ) for $6 \mathrm{MV}$ and $18 \mathrm{MV}$ photon energies. In addition, mass attenuation coefficients of various human tissues and water were computed with MATLAB (MATLAB and Statistics Toolbox Release 2018a, The MathWorks, Inc., Natick, Massachusetts, United States) and were compared with the NIST XCOM data.

\section{Material and Methods}

\section{Percentage Depth Dose Curves}

\section{Commissioning Of Experimental Measurements}

Experimental measurements were conducted with Varian LINAC (Clinac IX-DHX of Varian Medical Systems, Palo Alto, CA) armed with 60 pair of multi-leaf collimator (Millennium 120-leaf MLC) and on-board imaging system, which is located at Department of Radiation Oncology in Suleyman Demirel University Hospital, Turkey. Before starting commissioning procedure, the LINAC has been calibrated in terms of dose output and jaws position accuracy. Geometrical requirements for the measurement were done by setting the gantry and collimator angles to 0 degrees and aligning the water phantom collaterally. Commissioning of percentage depth dose (PDD) curves were done with MP3-M water phantom with a dimension of $50 \times 50 \times 40 \mathrm{~cm}$ (PWT, Freiburg, Germany) in a depth range from 0 to $25 \mathrm{~cm}$. $6 \mathrm{MV}$ and $18 \mathrm{MV}$ photon energies were used to acquire beam data. Water phantom measurements performed at square field sizes of $10 \times 10$ and $30 \times 30 \mathrm{~cm}^{2}$ with $0.125 \mathrm{cc}$ semi-flex ionization chamber with a scanning step size of $2 \mathrm{~mm}$ (PTW 31010, Freiburg, Germany). PDD curves, for the stated photon energies, were recorded at central axis of photon beam (Figure 1). MEPHYSTO software were used to analyze the recorded beam data.

\section{Linear Accelerator Simulation With Geant4}

Monte Carlo simulation is used in a big variety of applications such as; high energy physics and medical physics. In this study, Varian IX Clinac was modeled based on manufacturer- 
provided information with use of Geant4 (Geant4-09-06patch-02) Monte Carlo code. The Geant4, which is coded with the $\mathrm{C}++$ language, was employed to simulate the $6 \mathrm{MV}$ and 18 MV photon beams obtained from Geant4 libraries. Generally, Geant4 was founded at European Organization for Nuclear Research (CERN) for Large Hadron Collider (LHC) and is an object-oriented Monte Carlo simulation software. Geant4 was improved to model the transfer of any kind of particles throughout material. It contains different kind of physics models, providing for the interactions of electrons, hadrons, ions and muons with substance from $250 \mathrm{eV}$ up to number of peta-electron volts $(14,15)$. Numerous innovative illustrations are compared to biological and medical applications (hadron therapy, human phantom, brachytherapy, micro dosimetry, medical linac, etc.), which establishing the supremacy and ability of GEANT4 (16).

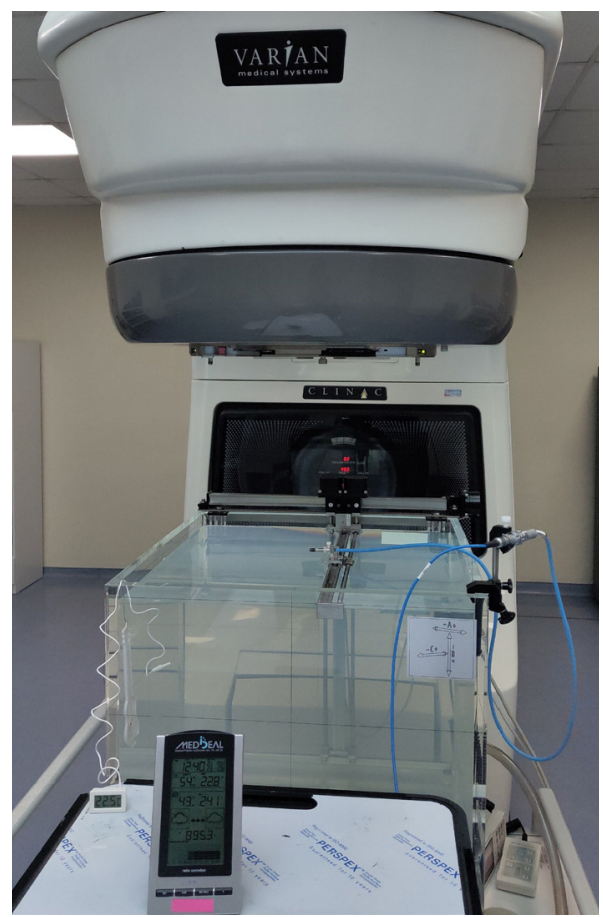

Figure 1. Experimental measurements set-up

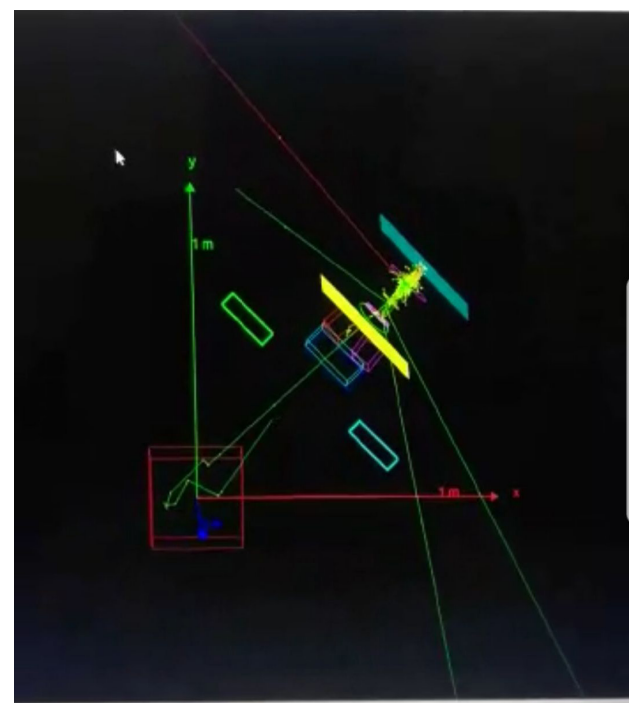

Figure 2. Model of medical linac simulation with Geant4
Geant4 simulated energy accumulation in a phantom, which was filled with water for a typical linac used in radiation therapy. The simulation set up was similar to one used in clinical work.

It consisted of basic six steps, which were experimental set up, environment variables, visualization, run, the physics and the data output in Geant4 (Figure 2). The geometries used for medical linac were source of electrons, the target, the ion chamber, the vacuum window, the primary collimator, the flattening filter, the mirror, the light field reticle and the water phantom. In modelling process, water phantom, which has dimensions of $50 \times 50 \times 40 \mathrm{~cm}$ was simulated with a source to surface distance $(\mathrm{SSD})$ of $100 \mathrm{~cm}$. In addition, the PDDs were simulated in a water phantom for various field sizes (10x10, 30×30).

\section{Mass Attenuation Coefficients}

In addition to measurements of PDDs, mass attenuation coefficients of various tissues and water were studied with MATLAB software, which provided set of functions for modeling of photons, passing through different organs and water. The calculations were based on attenuation and energy absorption coefficients of photons in various elements for organs. The mass attenuation coefficients were calculated in the initial energy range of 1-18 MeV. The tables of absorption coefficients were adapted in NIST and embedded in the MATLAB code. The used elemental distributions and their densities for the adult mesh type reference phantom for each tissue were calculated with ICRP Publication 110 (17). The resultant mass attenuation coefficients computed from MATLAB were compared with the XCOM data.

\section{Statistical Analysis}

Statistical analyses were performed using the SPSS software version 22 (Armonk, NY: IBM Corp., USA). Repeated measures analysis of variance was used to find the difference between the mean values of the parameters with normal distribution; in case of non-normal distribution, significance of the difference was analyzed using the Mann Whitney-U and Wilcoxon signed-ranks test. A p-value of less than 0.05 was considered to show a statistically significant result.

\section{Results}

Comparison of the experimental measurement and Geant4 Monte Carlo simulation results of PDD curves at $6 \mathrm{MV}$ and $18 \mathrm{MV}$ photons for $10 \times 10$ and 30x30 cm2 square field sizes are presented are shown in Figure 3 and Figure 4.

The computed mass attenuation coefficients of various human tissues and water by using MATLAB and the comparison with provided data by XCOM are presented in Figure 4-Figure 10. In some tissues, there is no difference between male and female results; such as muscle, skin and bone. Because of that, the resultant graphs were classified under the same figures. Median percentage differences of MATLAB vs XCOM for the investigated tissues and water were presented in Figre 11. While the maximum median percentage difference of MATLAB with a comparison of XCOM were recorded for muscle tissue with a result of $3.365 \%(0.050 \%-6.232 \%)$, the 
minimum median percentage difference was calculated for water with a result of $1.234 \%(0.000 \%-2.643 \%)$. Moreover, for human tissue the minimum median percentage difference was computed for skin with a value of $2.186 \%(0.000 \%$ $4.380 \%)$.

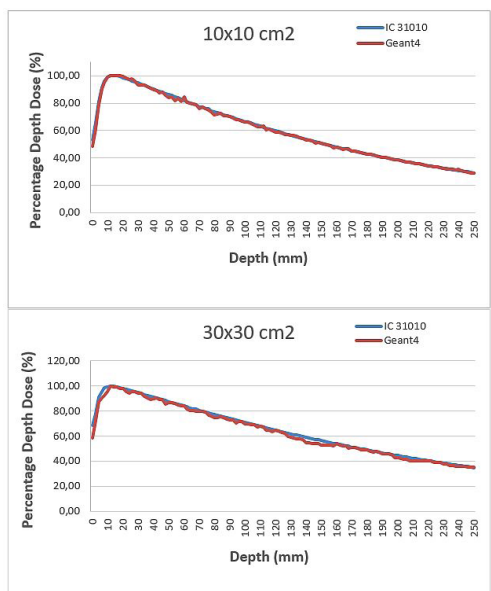

Figure 3. Obtained percentage depth dose curves of $6 \mathrm{MV}$ photon energy with ionization chamber and Monte Carlo simulation (Geant4) for $10 \times 10 \mathrm{~cm}^{2}$ and $30 \times 30 \mathrm{~cm}^{2}$ field sizes

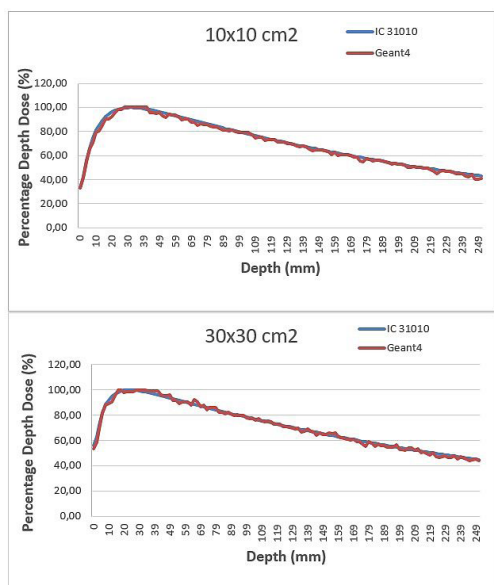

Figure 4. Obtained percentage depth dose curves of $18 \mathrm{MV}$ photon energy with ionization chamber and Monte Carlo simulation (Geant4) for $10 \times 10 \mathrm{~cm}^{2}$ and $30 \times 30 \mathrm{~cm}^{2}$ field sizes

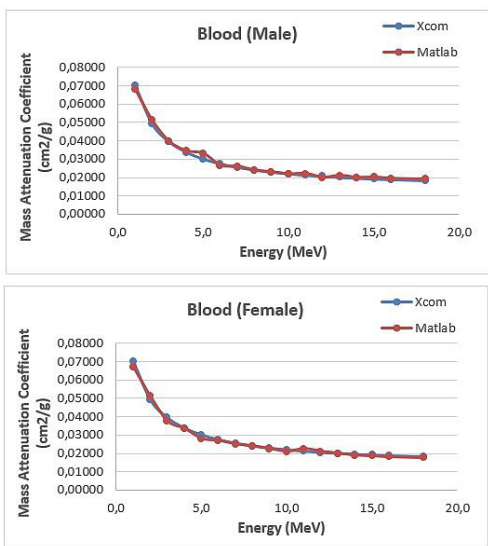

Figure 5. Calculated mass attenuation coefficients for male blood and female blood

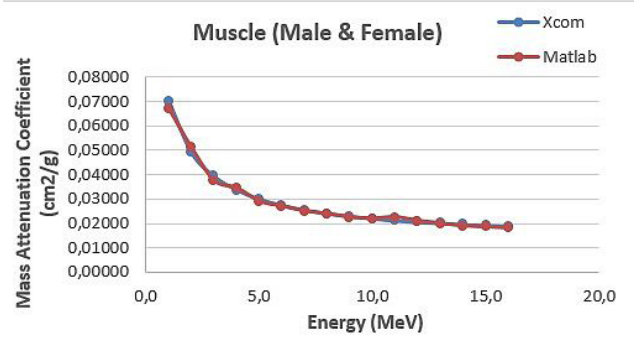

Figure 6. Calculated mass attenuation coefficients for both male and female muscle

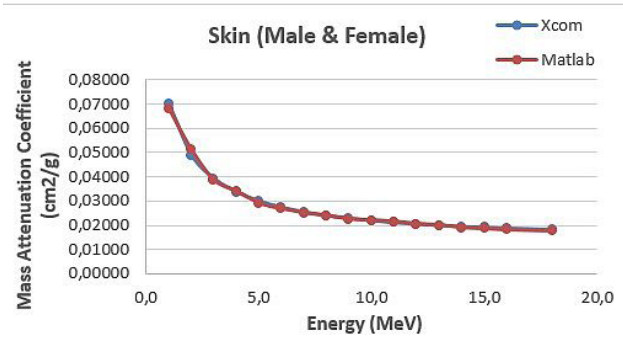

Figure 7. Calculated mass attenuation coefficients for both male and female skin

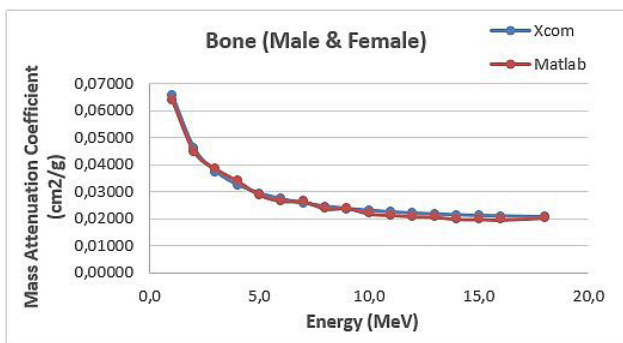

Figure 8. Calculated mass attenuation coefficients for both male and female bone
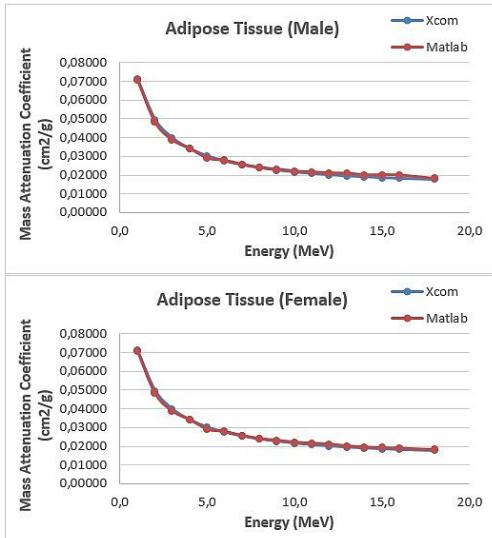

Figure 9. Calculated mass attenuation coefficients for male adipose tissue and female adipose tissue

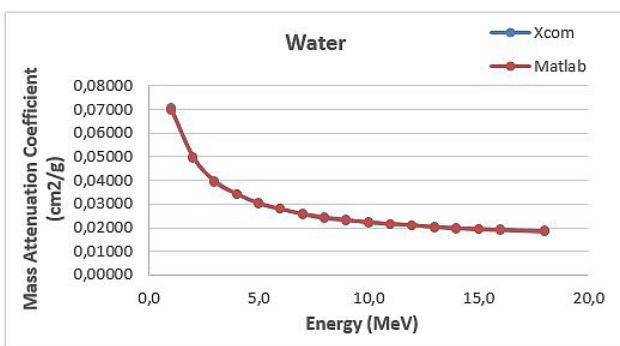

Figure 10. Calculated mass attenuation coefficients for water 


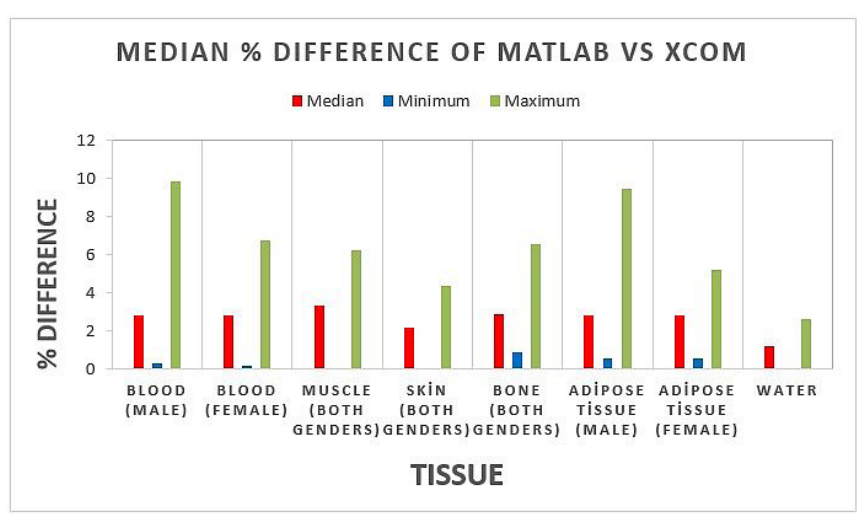

Figure 11. Median, minimum and maximum percentage differences of MATLAB vs XCOM for the investigated tissues and water

The resultant values of the statistical analyses for PDD measurements and computed mass attenuation coefficient are displayed in Table 1 and Table 2, Table 3, respectively. As a result of the normality test, the obtained skewness and kurtosis values indicated that PDD data and mass attenuation coefficient results showed non-normal distribution. Furthermore, distribution curves verified that data collected from measurements were conformed to the non-normal distribution for all PDD and mass attenuation coefficient values. Moreover, the Wilcoxon signed-ranks test results between measurements of experimental and Geant 4 showed that the differences between these two measurement techniques were statistically significant for both $6 \mathrm{MV}$ $(p<0.001)$ and $18 \mathrm{MV}$ photon energies $(p<0.001$ for $10 \times 10$ $\mathrm{cm} 2$ and $\mathrm{p}<0.05$ for $30 \times 30 \mathrm{~cm}^{2}$ ). On the other hand, statistical analyses result of mass attenuation coefficients were more complicated. The results of Mann Whitney-U test (Table 2) showed that no statistically significant differences were found between male and female results for the mentioned tissues ( $p>0.05$ ). The results of Wilcoxon signed-ranks test (Table 3 ) indicated that no statistically significant difference between MATLAB and XCOM were found for all mentioned human tissues, except for bone ( $\mathrm{p}=0.039$ for bone in both genders).

Table 1. p-values of ionization chamber and Geant 4 for different field sizes

\begin{tabular}{lcc}
\hline & $\mathbf{1 0 \times 1 0 \mathbf { c m } ^ { 2 }}$ & $\mathbf{3 0 \times 3 0 \mathbf { c m } ^ { 2 }}$ \\
\hline $\mathbf{6} \mathrm{MV}$ & $<0.001^{*}$ & $<0.001^{*}$ \\
$\mathbf{1 8} \mathrm{MV}$ & $<0.001^{*}$ & $<0.015^{* *}$ \\
\hline * &
\end{tabular}

*Denotes that difference is statistically significant at 0.001 level (2-tailed)

**Denotes that difference is statistically significant at 0.05 level (2-tailed)

Table 2. p-values of mass attenuation coefficients for various tissues with both genders

\begin{tabular}{lcc}
\hline & $\begin{array}{c}\text { XCOM } \\
\text { Male vs Female }\end{array}$ & $\begin{array}{c}\text { MATLAB } \\
\text { Male vs Female }\end{array}$ \\
\hline Blood & 0.850 & 0.679 \\
Bones & 1.000 & 1.000 \\
Adipose Tissue & 0.877 & 0.836 \\
Muscle & 1.000 & 1.000 \\
Skin & 1.000 & 1.000 \\
\hline
\end{tabular}

Table 3. $p$-values of mass attenuation coefficients for various tissues and water with XCOM and MATLAB

\begin{tabular}{lcc}
\hline & $\begin{array}{c}\text { MALE } \\
\text { Xcom vs Matlab }\end{array}$ & $\begin{array}{c}\text { FEMALE } \\
\text { Xcom vs Matlab }\end{array}$ \\
\hline Blood & 0.093 & 0.076 \\
Bones & $\mathbf{0 . 0 3 9 *}$ & $\mathbf{0 . 0 3 9 *}$ \\
Adipose Tissue & 0.093 & 0.246 \\
Muscle & 0.185 & 0.185 \\
Skin & 0.088 & 0.088 \\
Water & \multicolumn{2}{c}{$\mathbf{0 . 0 0 8 *}$} \\
*Denotes that difference is statistically significant at 0.05 level (2-tailed)
\end{tabular}

\section{Discussion}

As can be seen from Table 1, Figure 3 and Figure 4, even though statistical analyses indicated that the differences between the results of Geant4 and experimental measurements were significant for PDD curves, good agreement was observed with the Monte Carlo results and experimental measurement qualitatively. Due to the large number of sampling points in PDD measurements, small variances in the results of two measurement methods yielded a statistically significant difference. Ripples in percentage depth dose curves were more evident with the results of Geant 4 for the field size of $30 \times 30 \mathrm{~cm}^{2}$. The consistency of Geant 4 with experimental results was more explicit for $6 \mathrm{MV}$ photons with the field size of $10 \times 10 \mathrm{~cm}^{2}$.

Similarly Ding, Sardari et al., reported that particularly in the build-up region and in deeper sampling points, the coherence between Monte Carlo results and experimental measurements were impaired $(18,19)$. In this current study; similar outcomes were obtained that the discrepancies were more noticeable, especially for both $6 \mathrm{MV}$ and $18 \mathrm{MV}$ photon energies with field size of $30 \times 30 \mathrm{~cm}^{2}$.

Mesbahi et al. compared the MCNP4C and the GEANT3 code with the experimental measurements for $6 \mathrm{MV}$ and 15 MV photon beams with different field sizes in Varian Clinac $2300 \mathrm{C} / \mathrm{D}$. They reported that the variances between computed and measured PDDs in the downward part of the curves had been less than $1.2 \%$ for both codes and in the build-up region, these variances increased up to $7 \%$ for both codes (20). Similarly, in this current study for $6 \mathrm{MV}$ photon beam in the build-up region, differences between Geant 4 and measured PDDs values were less than $8 \%$. In the tail part of the PDD curve the differences were decreased considerably to below $2 \%$. Remarkably, for both field sizes, the differences in dose maximum region were found to be less than $1 \%$.

The computed mass attenuation coefficients of various human tissues and water by using MATLAB and the comparison with provided data by XCOM are presented in Figure 4-Figure 10. As can be seen from Table 2, for the study of mass attenuation coefficients, no differences were recorded between male and female results; for the human tissues of muscle, skin and bone within XCOM and MATLAB calculations $(p=1.000)$. Because of that, the resultant graphs were classified under the same figures for both genders. 
Akar et al. measured the mass attenuation coefficients of muscle, bone, fat and water in low-energy photon energies (140 $\mathrm{keV}, 364 \mathrm{keV}$ and $662 \mathrm{keV}$ ) and compared the experimental results with the Hubbell and Seltzer data (21). Akar et al. reported a good agreement with the Hubble and Seltzer data by fitting his findings to the mass attenuation curve of NIST (22). Reported results from Hubbell and Seltzer data were fairly close to our findings with the computed XCOM results in this current study.

Tekin et al. investigated the mass attenuation coefficients of various human body organs by comparing the findings with the most used Monte Carlo platforms such as FLUKA, MCNP-X, and GEANT4 and with the data provided by XCOM and NIST for photon energies below $2 \mathrm{MeV}$ (9). In this current study, the results of $1 \mathrm{MeV}$ and $2 \mathrm{MeV}$ were matched up with findings of the mentioned study for the tissues of blood, adipose tissue, bone, muscle and skin with XCOM data. On the other hand, the outcomes of MATLAB computations weren't overlap as much as XCOM data. However, this result should not lead one to a proven inference that MATLAB was better at high energy moving particles for the estimation of mass attenuation coefficients.

It was found that water was the best match up material between XCOM and MATLAB results. This can be very useful outcome considering that the human body is consisting of water to a large extent. Furthermore, MATLAB also simulated skin tissue considerably well compared with XCOM (Figure 11).

\section{Conclusion}

In this current study, Varian IX medical LINAC was simulated via using Geant4 based on manufacturer's information. Percentage depth dose curves with different photon energy and field sizes in a water phantom were verified by using Geant4 simulation tool. Although some discrepancies were recorded due to the electron contamination in the buildup region of percentage depth dose curves; generally, a good consistence was observed with the Geant 4 results and experimental measurement indicating that Geant 4 can be used to predict percentage depth dose curves for medical linacs. On the other hand, this research showed that MATLAB code is an applicable and competent code for computing mass attenuation coefficients in high-energy fields. In addition, mass attenuation coefficients calculated with MATLAB yielded consistent results with previous studies, which means MATLAB can be used as an alternative simulation tool for estimating mass attenuation coefficients of various human tissues, as well as water material. Moreover, the computed results of mass attenuation coefficients with MATLAB was determined as a baseline for further studies. The results of this study verified that MC simulation tools are one of the promising modalities of clinical researches and can be implemented for medical physics studies.

\section{References}

1. Gottfried KLD, Penn G, editors. Radiation in Medicine: A Need for Regulatory Reform. Washington (DC): National
Academies Press (US); 1996. Clinical Applications of Ionizing Radiation.

2. Caccia B, Andenna C, Cirrone GA. MedLinac2: a GEANT4 based software package for radiotherapy. Ann Ist Super Sanita. 2010;46(2):173-177.

3. Stewart BW, Wild CP, editors. World cancer report 2014. Lyon: International Agency for Research on Cancer; 2014.

4. Xu XG, Bednarz B, Paganetti H. A review of dosimetry studies on external-beam radiation treatment with respect to second cancer induction. Phys Med Biol. 2008;53(13):R193R241.

5. Agostinelli S, Allison J, Amako K, Apostolaki J, Araujo $\mathrm{H}$, Arce P, et al. Geant4 - a simulation toolkit. Nuclear Instruments and Methods in Physics Research Section A: Accelerators, Spectrometers, Detectors and Associated Equipment. 2003;56(3):250-303.

6. El Bakkali J, El Bardouni T. Validation of Monte Carlo Geant4 code for a $6 \mathrm{MV}$ varian linac. J. King Saud Univ Sci. 2017;29:106-13.

7. Carrier JF, Archambault L, Beaulieu L. Validation of GEANT4 (an object-oriented Monte Carlo toolkit) for simulations in medical physics. Med Phys. 2004;31:484-92.

8. Kienböck R. Über Dosimeter und das quantimetrische Verfahren. Fortschritte auf dem Geb Röntgenstrahlen. 1905;9:276-95.

9. Tekin HO, Singh VP, Altunsoy EE, Manici T, Sayyed M. Mass attenuation coefficients of human body organs using MCNPX Monte Carlo code. Iran J Med Phys. 2017;14:229-40.

10. Jones AK, Hintenlang DE and Bolch WE. Tissueequivalent materials for construction of tomographic dosimetry phamtons in pediatric radiology. Med Phys. 2003;30:2072-81.

11. International Commission on Radiation Units and Measurements. Tissue substitutes in radiation dosimetry and measurement, ICRU Report 44. Bethesda, MD, USA:ICRU;1989.

12. Valentin J. Basic anatomical and physiological data for use in radiological protection: reference values: ICRP Publication 89. Annals of the ICRP. 2002;32:1-277.

13. Hubbell JH. Review and history of photon cross section calculations. Phys Med Biol. 2006;51:245-62.

14. Foppiano F, Mascialino B, Pia MG, Piergentili M. A Geant4 based simulation of an accelerator head for intensity modulated radiation therapy. IEEE Symposium Conference Record Nuclear Science 2004; 2004 Oct 16-22; Rome, pp. 2128-32 Vol. 4.

15. Chauvie S, Depaola G, Ivanchenko V, Longo F, Nieminen P, Pia MG. Geant4 low energy electromagnetic physics. In: Proceedings of Computing in High Energy and Nuclear Physics; 2001; Beijing, China, pp. 337-40.

16. Cirrone GAP, Cuttone G, Guatelli S, Lo Nigro S, Mascialino B, Pia MG, et al. Implementation of a new Monte Carlo - GEANT4 simulation tool for the development of a proton therapy beam line and verification of the related 
dose distributions. IEEE Transactions on Nuclear Science. 2005;52(1):1756-8.

17. Menzel HG, Clement C, \& DeLuca P. ICRP Publication 110. Realistic reference phantoms: an ICRP/ICRU joint effort. A report of adult reference computational phantoms. Annals of the ICRP. 2009;39(2):1-164.

18. Ding GX. Dose discrepancies between Monte Carlo calculations and measurements in the buildup region for a high-energy photon beam. Med Phys. 2002;29:2459-63.

19. Sardari D, Maleki R, Samavat H, Esmaeeli A. Measurement of depth-dose of linear accelerator and simulation by use of Geant4 computer code. Reports of Practical Oncology \& Radiotherapy. 2010;15:64-8.

20. Mesbahi A, Fix M, Allahverdi M, Grein E, Garaati H.
Monte Carlo calculation of Varian 2300C/D linac photon beam characteristics: a comparison between MCNP4C, GEANT3 and measurements. Appl Radiat Isot. 2005;62:469-77.

21. Akar A, Baltas H, Cevik U, Korkmaz F, Okumusoglu NT. Measurement of attenuation coefficients for bone, muscle, fat and water at 140,364 and $662 \mathrm{keV} \gamma$-ray energies. Journal of Quantitative Spectroscopy and Radiative Transfer. 2006;102:203-11.

22. Hubbell JH, Seltzer SM. Tables of X-ray mass attenuation coefficients and mass energy-absorption coefficients from 1 $\mathrm{keV}$ to $20 \mathrm{MeV}$ for elements $\mathrm{Z} 1 / 41$ to 92 and 48 an additional substances of dosimetric interest. National Institute of Standards and Technology, Physical Reference Data. 1995; p. 5632 . 